\title{
Surfactant Protein C Gene (SFPTC) Mutation-Associated Lung Disease: High-Resolution Computed Tomography (HRCT) Findings and its Relation to Histological Analysis
}

\begin{tabular}{|c|c|}
\hline Journal: & Pediatric Pulmonology \\
\hline Manuscript ID: & PPUL-10-0006.R2 \\
\hline Wiley - Manuscript type: & Original Article \\
\hline $\begin{array}{r}\text { Date Submitted by the } \\
\text { Author: }\end{array}$ & 12-May-2010 \\
\hline Complete List of Authors: & $\begin{array}{l}\text { Mechri, Meriem; Hopital Armand Trousseau, Pediatric Radiology } \\
\text { department } \\
\text { epaud, ralph; Hôpital Armand Trousseau, Pediatric Pulmonary } \\
\text { Department, INSERM UMR-S 938 } \\
\text { emond, sophie; Necker Enfants Malades hospital, pediatric } \\
\text { pulmonology } \\
\text { Coulomb, Aurore; Hôpital Armand Trousseau, Histological } \\
\text { Department } \\
\text { jaubert, francis; Necker Enfants Malades hospital, laboratoire } \\
\text { d'anatomopathologie } \\
\text { feldmann, delphine; armand Trousseau hospital, laboratoire de } \\
\text { biochimie } \\
\text { Clément, Annick; AP-HP, Hopital Armand Trousseau, Pediatric } \\
\text { pulmonology and INSERM UMR S-719 } \\
\text { Tarrant, Ailbhe; Hôpital Armand Trousseau, Pediatric Radiology } \\
\text { department } \\
\text { de Blic, Jacques; Necker Enfants Malades, Pneumology } \\
\text { ABOU TAAM, ROLA; Necker Enfants Malades hospital, pediatric } \\
\text { pulmonology } \\
\text { Brunelle, Francis; Hopital Necker Enfants malades, Pediatric } \\
\text { Radiology Deparment } \\
\text { Ducou Le pointe, Hubert; Hôpital Armand Trousseau, Pediatric } \\
\text { Radiology department }\end{array}$ \\
\hline Keywords: & surfactant, radiological, Histological, HRCT \\
\hline
\end{tabular}

\section{(5) ScholaroNE \\ Manuscript Central}




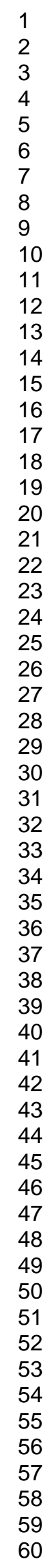

John Wiley \& Sons, Inc. 


\section{Surfactant Protein C Gene (SFTPC) Mutation-Associated Lung Disease:}

High-Resolution Computed Tomography (HRCT) Findings and its Relation to Histological Analysis

M. Mechri ${ }^{* 1,2,3}$, R. Epaud ${ }^{* 2,3,4,5}$, S. Emond ${ }^{1,6,7}$, A. Coulomb ${ }^{2,3,8}$, F. Jaubert ${ }^{1,6,8}$, A. Tarrant ${ }^{1,2,3}$, D. Feldmann $^{2,3,9}$, F. Flamein ${ }^{2,4}$, A. Clement ${ }^{2,3,4,5} \mathrm{~J}_{\text {. de Blic }}^{5,6,7}$, R. Abou Taam ${ }^{5,6,7}$, F. Brunelle ${ }^{1,6,7}$, H. Ducou le Pointe ${ }^{1,2,3}$

${ }^{1}$ Pediatric Radiology Department. ${ }^{2}$ UPMC Univ Paris 06, France; ${ }^{3}$ AP-HP, Hôpital Armand Trousseau, ${ }^{4}$ INSERM UMR_S U938, Paris, France; ${ }^{5}$ Pediatric Pulmonary Department; ${ }^{6}$ Université Paris Descartes ; ${ }^{7}$ AP-HP, Hôpital Necker Enfants Malades, Paris, France; ${ }^{8}$ Histological department, ${ }^{9}$ Biochemistry Department.

*These authors contributed equally to this work and should be considered as first author.

The authors have no conflicts of interest to disclose.

Running title: HRCT and histological finding of SFTPC mutations

Keywords: surfactant protein C, HRCT, Histological.

\section{Corresponding authors:}

\section{Pr. Hubert Ducou Le pointe}

Pediatric Radiology Department

Hôpital d'Enfants Armand Trousseau

26 Avenue du Dr Arnold Netter

F-75571 Paris cedex 12, France

Email : hubert.ducou-le-pointe@trs.aphp.fr 
Abstract:

\section{Aim of the study}

Determine high-resolution tomography (HRCT) scan characteristics in children with SFTPC mutation and correlate them to histological findings.

\section{Patients and Methods}

This retrospective multicenter study included 15 children (7 females and 8 males) with SFTPC mutations. HRCT scans have been performed in all the children and lung biopsies in 8 children.

\section{Results}

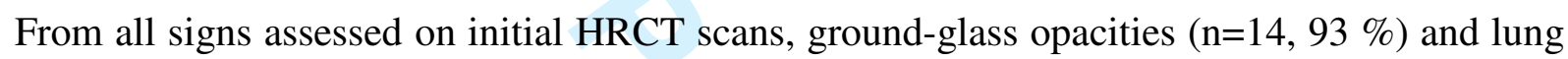
cysts $(n=6,40 \%)$ were predominant. Interlobular septal thickening $(n=1,7 \%)$, air space consolidation $(\mathrm{n}=1,7 \%)$, paraseptal emphysema $(\mathrm{n}=2,13 \%)$, and pulmonary nodules $(\mathrm{n}=1,7$ $\%)$ were also found. Histological analysis revealed accumulation of macrophages in the alveolar lumen, type II pneumocyte hyperplasia, and alveolar septal thickening. Dilatation of the respiratory bronchiole and alveolar duct associated with muscular hyperplasia were also described. Interestingly, lung cysts on HRCT scans were associated with dilatation of terminal bronchioli and alveolar duct in lung biopsies.

\section{Conclusion}

In children with SFTPC mutations, HRCT scan finding were highly correlated to the histological findings and, as such, represent a useful tool to identify patients that may require SFTPC gene sequencing. 


\section{Introduction:}

Idiopathic forms of interstitial lung disease (ILD) in children are associated with a wide spectrum of underlying pathologies. Until recently, a single classification system has been used, regardless of age, and children with ILD were forced into published adult disease classification systems ${ }^{1}$. In 2007, a multi-disciplinary working group of pediatric pathologists, clinicians and radiologist (the Children's Interstitial Lung Disease (chILD) Research Cooperative) designed and conducted a retrospective clinical, radiographic and histopathologic review and proposed a new classification system for children with diffuse lung disease (chILD syndrome) ${ }^{2}$. In this classification, surfactant genetic abnormalities account for more than $10 \%$ of the patients reviewed. Pulmonary surfactant is a mixture of phospholipids and specific proteins secreted by type II epithelial cell to reduce the alveolar surface tension at the air-liquid interface and prevent end-expiratory atelectasis ${ }^{3}$. The hydrophobic surfactant protein SP-C, play an important role in the spreading and stabilization of phospholipids films in the alveolus ${ }^{3}$ highlighted by lung disease caused by inherited abnormalities in its genes ${ }^{4,5}$. Since the first description by Nogee et al., more than 35 dominantly expressed mutations in the SFTPC gene have been identified in association with acute or chronic lung disease in patients ranging in age from newborn to adults ${ }^{6-10}$. These mutations, whether inherited or spontaneous are always found in an autosomal dominant form, the most frequently observed (nearly $50 \%$ ) being p.[Ile73Thr] or I73T). The phenotype associated with SFTPC mutations is eminently variable. Indeed, neonatal forms leading to death in the first years of life as well as childhood and adult forms with chronic respiratory disease have been observed. The effects of SFTPC mutations on surfactant homeostasis have not been clearly elucidated. In an in vitro study off cells with a SFTPC deletion, accumulation of misfolded proSP-C in the Endoplasmic reticulum (ER) causes disruption of the ubiquitin/proteasome system ${ }^{11}$, activates apoptosis and interferes with non mutated protein 
synthesis. It results in the release of pro-inflammatory cytokines and enhances T-cell and fibroblast recruitment ${ }^{12}$.

Although consensus exists on the need to consider early open lung in children with ILD, genetic testing for SFTPC mutation has become widespread and may be performed relatively quickly. In addition, recent advances in imaging techniques have contributed to more efficiently predict histological findings. Indeed, HRCT has been proposed for either diagnosis or following ILD precluding the need to obtain a surgical biopsy ${ }^{13,14}$. Thus, the aim of the present study was to determine HRCT features of children with SFTPC mutation and to bring new insight in the correlation between HRCT and histological findings. To address these questions HRCT finding of a cohort of 15 children with interstitial chronic lung disease related to SFTPC gene mutations were retrospectively reviewed and subsequently correlated with histological analysis when lung biopsies were available. 


\section{Patients and Methods}

This study is a retrospective study performed in 2 university hospital-based pediatric pulmonology practice (Hôpital Armand Trousseau and Hôpital Necker enfants-malades, Paris, France) for a 15-year period (1993-2008). The protocol was accepted by the Committee for the protection of individuals in Biochemical research as required by French legislation and written informed consent was obtained from the patients or their next of kin included in this study.

\section{Patients}

The characteristics of patients are summarized in Table 1. Fifteen children, 7 females and 8 males with a definitive diagnosis of SFTPC gene mutation were included. All the patients were immunocompetent and screening for metabolic, infectious, and immunological etiologies was negative. Genetic and clinical characteristics of all these patients have been described in detail in previous reports ${ }^{8,15}$. Three patients, members, or relatives of a same family, have also been reported previously ${ }^{6}$. Median age of onset was 2 (range 0-18) months. Three patients had neonatal respiratory distress, and symptom onset was associated with acute bronchiolitis in $7(47 \%)$ patients. Cough, tachypnea, and gastroesophageal reflux and failure to thrive were initially noticed in all the children. Physical examination at presentation revealed tachypnea and retraction in all patients. Low oxygen saturation $(<95 \%)$ was observed initially in all patients. Treatment are summarized in table 1 and included methylprednisolone pulse $(n=15)$, hydroxychloroquin $(n=8)$ and azithromycin $(n=5)$. Median follow-up was 3.1 (1-17.3) years. At the end of the study, all the children were alive but 11 patients (73\%) were still symptomatic with cough, dyspnea or exercise intolerance. 


\section{HRCT scan and image analysis}

CT examinations were performed with two helical scanners and two multidetector CT scanners. In Armand Trousseau hospital, Elscint (CT Twin) with scan acquisition at $120 \mathrm{kV}$, 120 mAs and after 2003 a Philips (Mx 8000 IDT32) 16 slice multidetector CT was used with scan acquisition at the $90 \mathrm{kV}, 90 \mathrm{mAs}$. In Necker Hospital, General Electric helical CT (Prospeed) with scan acquisition at $140 \mathrm{kV}, 130 \mathrm{mAs}$, and after 2005 a General Electric (LightSpeed) 64 slice multidetector CT was used with scan acquisition at the $100 \mathrm{kV}, 100 \mathrm{~mA}$. All the patients underwent non-contrast-enhanced incremental (at intervals of 3 to $10 \mathrm{~mm}$ ) or helical HRCT scan with a collimation of 16 X $1 \mathrm{~mm}$. Scans were obtained from the level of apices to the diaphragm. Image reconstruction was performed with a high special frequency algorithm. All CT scans were performed before the diagnosis, and none of the patients were receiving treatment at the time of first HRCT. The HRCT scans (initial and follow-up) were reviewed and interpreted by 2 experienced pediatric radiologists who arrived at their interpretations by consensus without knowledge of histological parameters. HRCT scan analysis was performed with reference to a conventional model in line with Austin's definition

The scans were assessed for the presence, extent, and distribution of elementary lesions, such us areas of ground-glass opacity, lung cysts, lung consolidation, interlobular and intralobular septal thickening, thickening of bronchovascular bundles, and nodules (centrolobular or other). The anatomical distribution was classified as central (a predominance of abnormalities in the inner two-thirds of the lung), peripheral (a predominance of abnormalities in the outer one-third of the lung or along the interlobar fissures), or random (no central or peripheral predominance). The zonal predominance of abnormalities was assessed as being upper, intermediate lower, or random. Upper lung zone predominance was considered present when the extent of abnormalities was greatest above the level of the 
tracheal carina; intermediate was considered between the carina and inferior pulmonary veins, and lower zone predominance was considered present when disease extent was greatest below this level. Specific involvement or sparing of the subpleural region $(<1 \mathrm{~cm}$ from the pleura) was assessed. Ground-glass opacities describe lung that is higher in attenuation than a normal lung on inspiration but lower than the attenuation of bronchial walls and blood vessels so that these lung markings remain visible ${ }^{16}$. The term lung cyst is used to refer to a well-defined, rounded, and circumscribed lesion, with a wall that may be uniform or varied in thickness but which is usually thin (with thickness of less than $3 \mathrm{~mm})^{17}$. Because this study was retrospective, the intervals of follow-up HRCT scanners were highly centre-dependent and based on the decision of the physician in charge of the child. Only HRCT scanners available ware taking into consideration for analysis. Control HRCT scans were obtained from 6 agematched patients with a definitive diagnosis of $A B C A 3$ (ATP-binding cassette subfamily A, member 3) mutations, a gene expressed in lamellar bodies of alveolar type II cells which has a critical role in surfactant storage and homeostasis ${ }^{18}$. Among them, 2 patients carried homozygous missense mutations, 3 patients carried compound heterozygous missense mutations and 1 child had compound heterozygous missense and nonsense mutations. Median age at HRCT scans was 2 months (range 1 month to 12 years).

\section{Lung biopsies and their analysis}

Surgical lung biopsies ranging from 0.5 to $1 \mathrm{~cm}$ were obtained from different lobes in 8 children at the age of 3 to 7 months (mean age, 4 months) before treatment onset. Biopsy sites are summarized in Table 1. Specimens were further fixed in formalin and embedded in paraffin. A five-micrometer tissue section was stained with $\mathrm{H}$ and $\mathrm{E}$ stain (hematoxylin and eosin stain). Slides were examined by 2 pathologists. Radiology-pathology correlation was performed in 8 cases. All 8 children had only 1 open lung biopsy. 


\section{Results:}

\section{Initial HRCT findings}

The median age at initial HRCT scanner was 4 (range 1-40) months (one child had the scanner performed 40 months after the diagnosis for technical reasons). High-resolution CT findings are summarized in Table 2. The most frequent abnormalities identified on initial HRCT were ground-glass opacities (93\%) and lung cysts (40\%). Other abnormalities noted included interlobular septal thickening (7\%), air space consolidation (7\%), paraseptal emphysema (13\%), and pulmonary nodules (7\%). In comparison, ground-glass opacities were constantly observed in all of the 6 patients with ABCA3 mutations. However, opacities were more prominent with presence in some cases of alveolar condensations.

Bilateral ground-glass opacities were shown in 14 children (Table 3), either as an isolated finding (60\%) or as part of a mixed pattern with lung cysts (33\%), air space consolidation (7 $\%)$, paraseptal emphysema, and centrolobular nodules (7 \%). They were homogeneously diffuse in 9 cases $(60 \%)$ (Figure 1A). When a patchy distribution was present, this was noted to have basal subpleural predominance in 1 case $(7 \%)$, predominance for the lower lobes in 2 cases (13\%) (Figure 1B), a central predominance in 1 case $(7 \%)$, and a predominance for the posterior portions of the lung in 1 case $(7 \%)$.

Thin-walled $(<1 \mathrm{~mm})$ lung cysts of varying sizes were seen in 6 infants (40\%) (Table 4), either as an isolated finding (7\%) (Figure $2 \mathrm{~A})$, or as a mixed pattern with areas of groundglass opacities (33\%), paraseptal emphysema (13\%) (Figure 2B), septal thickening (7 \%), and non-septal thickening ( $7 \%$ ). A predominantly subpleural distribution was seen in 1 child (7\%); diffuse cysts with random distribution was seen in 4 cases $(27 \%)$ and upper lung zone predominance was seen in 1 case $(7 \%)$.

Follow-up HRCT scan 
Follow-up CT scans were performed on 11 of the 15 children. The median follow-up interval was 8 (range 3-12) months. Eight patients had 1 follow-up HRCT scan, 2 patients had 2 follow-up HRCT scans ( 3 and 9 months and 4 and 9 months, respectively), and 1 patient had 3 follow-up HRCT scans (3, 6 and 12 months). Evaluation of the follow-up HRCT scans (Table 5) revealed the development of lung cysts in 5 patients (45\%) who had previously only had ground-glass opacities (Figures 3A and 3B). These new cystic changes were associated with a stable pattern of ground-glass opacities in 2 cases, decrease in the degree of ground-glass opacities in 1 case, and an aggravation of this pattern in 2 cases. These cysts were diffuse in all cases but showed a predilection for different regions of the lung: upper lobes $(n=1)$, basal subpleural $(n=1)$, peripheral $(n=1)$, and central $(n=1)$. In 1 case, lung cysts were homogenous and diffuse. Patients who had previously documented cysts on their initial HRCT scans also demonstrated change when follow-up HRCT was performed. In 5 patients (45\%), we noted an increase in the number or size of preexisting lung cysts (Figures 4A and 4B), which were associated with stable ground-glass opacities $(n=4)$, aggravated ground-glass opacities $(n=1)$, and progressive pulmonary fibrosis $(n=1)$. The HRCT findings of pulmonary fibrosis consisted of bilateral and diffuse honeycombing, septal and non-septal thickening, and thickening of bronchovascular bundles and distortion of pulmonary fissures. In 1 patient, we observed persistent isolated ground-glass opacities.

\section{Pathology findings}

Eight of the 15 patients (53\%) underwent lung biopsy the median age at biopsy being 4 (range 3-7) months. Histological analysis revealed 2 main types of lesions. The first type occurred in the alveolar lumen, were we observed the following changes: accumulation of macrophages intermingled with few inflammatory cells and cholesterol cleft, type II pneumocyte hyperplasia, and alveolar septal thickening by primitive mesenchymal cells and lymphocytes either isolated or clustered (Figure 5A). These lesions were diffuse in 7 cases (90 


\section{Relation between HRCT and pathology findings}

Radiological-pathological confrontation is summarized in Table 6. Ground-glass opacities on HRCT were observed in all the patients except 1 in which the CT scan was performed late (40 months). All these children also have diffuse alveolar septal thickening by primitive mesenchymal cells and lymphocytes, intra-alveolar accumulation of macrophages, and type II pneumocyte hyperplasia. Small lung cysts were observed initially in half of the children but appeared during follow-up in all the cases. They were related with dilatation of the terminal bronchioles and alveolar duct which were noticed in all but one biopsy.

\section{Discussion:}

In the present study, we have shown for the first time in a large cohort of children with SFTPC mutation associated lung diseases that HRCT pattern were characterized with 2 main abnormalities: ground-glass opacities that were predominately diffuse but can be patchy in some cases and lung cysts with thin wall and different sizes.

Ground-glass opacities have been commonly described in previous reports ${ }^{6,19,20}$. They are predominately diffuse but can be patchy in some cases. In our series, they were present in all the patients except one in whom the HRCT scan was done late. We also note in our study the high frequency of cystic lesions on HRCT scan. They appeared in $45 \%$ of the children during follow-up and increased in number in $45 \%$. Similar change during follow-up is typical of surfactant abnormality and was noted by Brody ${ }^{16}$. In our series, ground-glass attenuation 
decreased in intensity with age, whereas small lung cysts usually became more prominent over time.

This HRCT presentation, namely the ground-glass opacities and cystic patterns is, nonetheless, not specific of SFTPC associated disorders. We have shown that this presentation may also be observed in children with $A B C A 3$ mutations as previously described ${ }^{21}$. However, the high frequency of SFTPC associated disorders in children ILD ${ }^{2,7}$, the feasibility of SFTPC genetic analysis as well as the difficulty to perform lung biopsy in patients with fragile respiratory condition strongly encourage to perform SFTPC genetic screening before lung biopsy in children with ground-glass opacities associated with cystic lung changes on HRCT scanner.

In the literature, there are histological studies of patients with SFTPC gene mutations showing 4 histological patterns: desquamative interstitial pneumonitis (DIP), nonspecific interstitial pneumonitis(NSIP), (UIP) and pulmonary alveolar proteinosis ${ }^{7,16,22}$ in children and usual interstitial pneumonitis (UIP) in adults. In children, DIP and NSIP have also been described in patients with mutations in the ATP-binding cassette transporter A3 (ABCA3) gene ${ }^{21}$. Chibbar et al. showed that both children and adults with NSIP and UIP patterns, respectively, carried a common mutation within the SFTPC gene ${ }^{23}$. Thomas et al. described a mutation in SFTPC gene associated with large kindred with familial form of pulmonary fibrosis, including adults with the most common pathological subset of pulmonary fibrosis, UIP, and children with cellular NSIP ${ }^{24}$. Brasch reported histological patterns of NSIP and pulmonary alveolar proteinosis in a 13-month-old infant with a de novo heterozygous missense mutation of the SFTPC gene ${ }^{20}$. The histological findings were classified as DIP because of an increased number of macrophages in the alveolar lumen ${ }^{25}$ and as NSIP and UIP because of the numerous inflammatory cells in the alveolar septum ${ }^{26,27}$. In this study, we have related ground-glass opacities on HRCT to diffuse alveolar septal thickening by primitive 


\section{Acknowledgement}

We thank all the members of the affected families and their referring clinicians for their collaborative participation in this study. This work was supported by Assistance PubliqueHôpitaux de Paris. "Surfactant Disorders and Chronic Lung Disease (APSE)," Clinical Trials gov. number, NCT00493363. 


\section{References:}

1. Demedts M, Costabel U. ATS/ERS international multidisciplinary consensus classification of the idiopathic interstitial pneumonias. Eur Respir J 2002;19(5):794796.

2. Deutsch GH, Young LR, Deterding RR, Fan LL, Dell SD, Bean JA, Brody AS, Nogee LM, Trapnell BC, Langston C, Albright EA, Askin FB, Baker P, Chou PM, Cool CM, Coventry SC, Cutz E, Davis MM, Dishop MK, Galambos C, Patterson K, Travis WD, Wert SE, White FV. Diffuse lung disease in young children: application of a novel classification scheme. Am J Respir Crit Care Med 2007;176(11):1120-1128.

3. Weaver TE, Conkright JJ. Function of surfactant proteins B and C. Annu Rev Physiol 2001;63:555-578.

4. Cole FS, Hamvas A, Nogee LM. Genetic disorders of neonatal respiratory function. Pediatr Res 2001;50(2):157-162.

5. Hamvas A. Inherited surfactant protein-B deficiency and surfactant protein-C associated disease: clinical features and evaluation. Semin Perinatol 2006;30(6):316326.

6. Abou Taam R, Jaubert F, Emond S, Le Bourgeois M, Epaud R, Karila C, Feldmann D, Scheinmann P, de Blic J. Familial interstitial disease with I73T mutation: A mid- and long-term study. Pediatr Pulmonol 2009;44(2):167-175.

7. Cameron HS, Somaschini M, Carrera P, Hamvas A, Whitsett JA, Wert SE, Deutsch G, Nogee LM. A common mutation in the surfactant protein $\mathrm{C}$ gene associated with lung disease. J Pediatr 2005;146(3):370-375.

8. Guillot L, Epaud R, Thouvenin G, Jonard L, Mohsni A, Couderc R, Counil F, de Blic J, Taam RA, Le Bourgeois M, Reix P, Flamein F, Clement A, Feldmann D. New surfactant protein $\mathrm{C}$ gene mutations associated with diffuse lung disease. J Med Genet 2009;46(7):490-494.

9. Hamvas A, Nogee LM, White FV, Schuler P, Hackett BP, Huddleston CB, Mendeloff EN, Hsu FF, Wert SE, Gonzales LW, Beers MF, Ballard PL. Progressive lung disease and surfactant dysfunction with a deletion in surfactant protein $\mathrm{C}$ gene. Am J Respir Cell Mol Biol 2004;30(6):771-776.

10. Lawson WE, Grant SW, Ambrosini V, Womble KE, Dawson EP, Lane KB, Markin C, Renzoni E, Lympany P, Thomas AQ, Roldan J, Scott TA, Blackwell TS, Phillips JA, 3rd, Loyd JE, du Bois RM. Genetic mutations in surfactant protein $\mathrm{C}$ are a rare cause of sporadic cases of IPF. Thorax 2004;59(11):977-980.

11. Mulugeta S, Nguyen V, Russo SJ, Muniswamy M, Beers MF. A surfactant protein C precursor protein BRICHOS domain mutation causes endoplasmic reticulum stress, proteasome dysfunction, and caspase 3 activation. Am J Respir Cell Mol Biol 2005;32(6):521-530.

12. Mulugeta $S$, Beers MF. Surfactant protein C: its unique properties and emerging immunomodulatory role in the lung. Microbes Infect 2006;8(8):2317-2323.

13. Hunninghake GW, Zimmerman MB, Schwartz DA, King TE, Jr., Lynch J, Hegele R, Waldron J, Colby T, Muller N, Lynch D, Galvin J, Gross B, Hogg J, Toews G, Helmers R, Cooper JA, Jr., Baughman R, Strange C, Millard M. Utility of a lung biopsy for the diagnosis of idiopathic pulmonary fibrosis. Am J Respir Crit Care Med 2001;164(2):193-196.

14. Silva CI, Muller NL, Hansell DM, Lee KS, Nicholson AG, Wells AU. Nonspecific interstitial pneumonia and idiopathic pulmonary fibrosis: changes in pattern and distribution of disease over time. Radiology 2008;247(1):251-259. 
15. Thouvenin G, Taam RA, Flamein F, Guillot L, Le Bourgeois M, Reix P, Fayon M, Counil F, Depontbriand U, Feldmann D, Pointe HD, de Blic J, Clement A, Epaud R. Characteristics of disorders associated with genetic mutations of surfactant protein $\mathrm{C}$. Arch Dis Child 2010.

16. Brody AS. Imaging considerations: interstitial lung disease in children. Radiol Clin North Am 2005;43(2):391-403.

17. Koyama M, Johkoh T, Honda O, Tsubamoto M, Kozuka T, Tomiyama N, Hamada S, Nakamura H, Akira M, Ichikado K, Fujimoto K, Rikimaru T, Tateishi U, Muller NL. Chronic cystic lung disease: diagnostic accuracy of high-resolution CT in 92 patients. AJR Am J Roentgenol 2003;180(3):827-835.

18. Shulenin S, Nogee LM, Annilo T, Wert SE, Whitsett JA, Dean M. ABCA3 gene mutations in newborns with fatal surfactant deficiency. $N$ Engl $J$ Med 2004;350(13):1296-1303.

19. Nogee LM, Dunbar AE, 3rd, Wert S, Askin F, Hamvas A, Whitsett JA. Mutations in the surfactant protein $\mathrm{C}$ gene associated with interstitial lung disease. Chest 2002;121(3 Suppl):20S-21S.

20. Brasch F, Griese M, Tredano M, Johnen G, Ochs M, Rieger C, Mulugeta S, Muller KM, Bahuau M, Beers MF. Interstitial lung disease in a baby with a de novo mutation in the SFTPC gene. Eur Respir J 2004;24(1):30-39.

21. Doan ML, Guillerman RP, Dishop MK, Nogee LM, Langston C, Mallory GB, Sockrider MM, Fan LL. Clinical, radiological and pathological features of ABCA3 mutations in children. Thorax 2008;63(4):366-373.

22. Tredano M, Griese M, Brasch F, Schumacher S, de Blic J, Marque S, Houdayer C, Elion J, Couderc R, Bahuau M. Mutation of SFTPC in infantile pulmonary alveolar proteinosis with or without fibrosing lung disease. Am $\mathbf{J}$ Med Genet A 2004;126(1):18-26.

23. Chibbar R, Shih F, Baga M, Torlakovic E, Ramlall K, Skomro R, Cockcroft DW, Lemire EG. Nonspecific interstitial pneumonia and usual interstitial pneumonia with mutation in surfactant protein $\mathrm{C}$ in familial pulmonary fibrosis. Mod Pathol 2004;17(8):973-980.

24. Thomas AQ, Lane K, Phillips J, 3rd, Prince M, Markin C, Speer M, Schwartz DA, Gaddipati R, Marney A, Johnson J, Roberts R, Haines J, Stahlman M, Loyd JE. Heterozygosity for a surfactant protein $\mathrm{C}$ gene mutation associated with usual interstitial pneumonitis and cellular nonspecific interstitial pneumonitis in one kindred. Am J Respir Crit Care Med 2002;165(9):1322-1328.

25. Lynch DA, Hay T, Newell JD, Jr., Divgi VD, Fan LL. Pediatric diffuse lung disease: diagnosis and classification using high-resolution CT. AJR Am J Roentgenol 1999;173(3):713-718.

26. Katzenstein AL, Myers JL. Nonspecific interstitial pneumonia and the other idiopathic interstitial pneumonias: classification and diagnostic criteria. Am J Surg Pathol 2000;24(1):1-3.

27. Kim TS, Lee KS, Chung MP, Han J, Park JS, Hwang JH, Kwon OJ, Rhee CH. Nonspecific interstitial pneumonia with fibrosis: high-resolution CT and pathologic findings. AJR Am J Roentgenol 1998;171(6):1645-1650.

28. Brenner DJ, Hall EJ. Computed tomography--an increasing source of radiation exposure. N Engl J Med 2007;357(22):2277-2284. 


\section{Figures:}

Fig. 1: Four-year-old boy with SFTPC mutation. HRCT section through the carina shows diffuse and uniform ground-glass opacities (A).Two-year-old girl with SFTPC mutation. Initial HRCT (at 3 months) shows homogenous ground-glass opacity in the lower lobes (B). One month old girl with compound heterozygous missense $A B C A 3$ mutations. Initial HRCT shows ground-glass opacity in the lower lobes (C).

Fig. 2: Two-year-old girl with SFTPC mutation. Initial HRCT (at 16 months) shows paraseptal emphysema (curved arrow) associated with widespread cystic airspaces and diffuse ground-glass opacities (A). Seventeen-year-old boy with SFTPC mutation. The HRCT done at 14 -year -old showed isolated lung cysts with thin wall and variable sizes (B). One month old girl with compound heterozygous missense $A B C A 3$ mutations. Initial HRCT shows association of ground-glass opacity, alveolar condensations and lung cysts (C).

Fig. 3: A one-year-old boy with SFTPC mutation. The initial computed tomography shows diffuse ground-glass opacities (A). The follow-up HRCT scan done 14 months later revealed the appearance of new lung cysts in lower lobes surimposed on diffuse ground-glass opacities (B).

Fig. 4: Two-year-old girl with SFTPC mutation. Initial HRCT scan diffuse shows lung cysts with subpleural predominance associated with diffuse ground-glass opacities (A). The followup HRCT scan done 6 months later, revealed an increase in the number and size of lung cysts associated with stable ground-glass opacities (B).

Fig. 5: A one-year old boy with SFTPC mutation who underwent lung biopsy in the middle lobe. High-power photomicrograph (original magnification $\times 200$, hematoxylin eosine $[\mathrm{H}-\mathrm{E}]$ stain) (A) shows numerous macrophages in alveoli (M) and type II pneumocytes hyperplasia (straight arrows) with septal thickening. HRCT section through the middle lobe (B) shows diffuse ground glass opacity.

Fig. 6: A 3-year old girl with SFTPC mutation who underwent lung biopsy in the right upper lobe. High- power photomicrograph (original magnification $\times 200$, hematoxylin eosine $[\mathrm{H}-\mathrm{E}]$ stain) (A) shows cystic distension of respiratory ducts (curved arrow), numerous macrophages in alveoli (M) and type II pneumocytes hyperplasia (straight arrows). HRCT section through the upper lobes (B) shows diffuse lung cysts associated with diffuse ground glass opacities. 
Table 1: Characteristics of patients

\begin{tabular}{|c|c|c|c|c|c|c|c|c|}
\hline $\begin{array}{l}\text { Patient } \\
\text { number }\end{array}$ & Sex & $\begin{array}{l}\text { Biopsy } \\
\text { (site) }\end{array}$ & $\begin{array}{l}\text { Age at onset } \\
\text { (months) }\end{array}$ & $\begin{array}{c}\text { Mutation (protein } \\
\text { level) }\end{array}$ & Familial (F)/de novo & Treatment & Oxygen status & $\begin{array}{l}\text { Follow up } \\
\text { (years) }\end{array}$ \\
\hline 1 & $\mathrm{~F}$ & Y(LIL) & 2 & p.[Ile73Thr] & $\mathrm{F}$ & MPP- A & SOO (47) & 4 \\
\hline 2 & $\mathrm{~F}$ & Y(LIL) & 2 & p.[Ile73Thr] & de novo & MPP-A & SOO (35) & 3 \\
\hline 3 & $\mathrm{~F}$ & $\mathrm{Y}(\mathrm{LIL})$ & 4 & p.[Ile73Thr] & de novo & MPP & OW (23) & 5.3 \\
\hline 4 & M & $\mathrm{N}$ & Birth & p.[Cys189Tyr] & $\mathrm{F}$ & MPP & OW (9) & 3 \\
\hline 5 & $\mathrm{~F}$ & $\mathrm{~N}$ & Birth & p.[Cys189Tyr] & $\mathrm{F}$ & MPP & OW (9) & 3 \\
\hline 6 & M & $\mathrm{Y}(\mathrm{LSL})$ & 4 & p.[Ile73Thr] & $\mathrm{F}$ & MPP-H & OW (7) & 3.6 \\
\hline 7 & $\mathrm{~F}$ & $\mathrm{~N}$ & 5 & p.[Ile73Thr] & $\mathrm{F}$ & MPP-H & OW (3) & 2.6 \\
\hline 8 & M & $\mathrm{N}$ & 2 & p.[Ile73Thr] & de novo & MPP & OW (24) & 5.5 \\
\hline 9 & M & Y(LSL) & 2 & p.[Leu188Pro] & de novo & MPP-H & OW (4) & 17.3 \\
\hline 10 & M & $\mathrm{N}$ & 15 & p.[Ile73Thr] & $\mathrm{F}$ & MPP-H & OW (10) & 3.3 \\
\hline 11 & $\mathrm{~F}$ & $\mathrm{~N}$ & 2 & p.[Ile73Thr] & $\mathrm{F}$ & MPP-H & OW (14) & 2.9 \\
\hline 12 & $\mathrm{~F}$ & Y(RIL) & 4 & p.[Val39Ala] & $\mathrm{F}$ & MPP-A & OW (14) & 15.4 \\
\hline 13 & M & Y(RML) & 2 & p.[Leu194Pro] & $\mathrm{F}$ & MPP-A-H & OW (7) & 1.8 \\
\hline 14 & M & Y(RSL) & 2 & p.[His142fs] & de novo & MPP-H & OW (7) & 3.6 \\
\hline 15 & $\mathrm{~F}$ & $\mathrm{~N}$ & 18 & p.[Ile73Thr] & de novo & MPP-A-H & SOO (12) & 1 \\
\hline
\end{tabular}

Biopsy: LIL, left inferior lobe; LSL, left superior lobe; RIL, Right inferior lobe; RML, right medium lobe; RSL, right superior lobe. Treatment: MPP, methylprednisolone pulse; H, hydroxychloroquin; A, azithromycin. Oxygen status: OW, oxygen weaning; SOO, still on oxygen; duration of oxygen (months) in paracenteses 
Table 2: Initial HRCT signs of patients with SFTPC gene mutation

\begin{tabular}{lcc}
\hline Initial HRCT findings & Patients & \\
& $(\mathrm{n}=15)$ & Controls (ABCA3 mutations) \\
& $1 \mathrm{n}=6)$ \\
\hline Ground-glass opacities & $14(93)$ & $6(100)$ \\
Lung cysts & $6(40)$ & $3(50)$ \\
Interlobular septal thickening & $1(7)$ & $2(30)$ \\
Consolidation & $1(7)$ & $2(30)$ \\
Paraseptal emphysema & $2(13)$ & $0(0)$ \\
Nodules & $1(7)$ & $0(0)$ \\
Lobe retractions & $0(0)$ & $1(17)$ \\
\hline Percentage of & & \\
\hline
\end{tabular}

Percentage of total is indicated in parentheses. 
Table 3: Distribution of ground-glass opacities on initial HRCT in patients with SFTPC gene mutation

\begin{tabular}{lcc}
\hline & $\begin{array}{c}\text { All patients } \\
(\mathrm{n}=15)\end{array}$ & $\begin{array}{c}\text { Patients with lung biopsy } \\
(\mathrm{n}=8)\end{array}$ \\
\hline Homogenous diffuse & $9(60)$ & $5(63)$ \\
Peripheral & $1(7)$ & $1(13)$ \\
Central & $1(7)$ & $0(0)$ \\
Posterior & $1(7)$ & $0(0)$ \\
Lower & $2(13)$ & $1(13)$
\end{tabular}

Percentage of total is indicated in parentheses. 
Table 4: Distribution of lung cysts on initial HRCT in patients with SFTPC gene mutation

\begin{tabular}{lcc}
\hline & $\begin{array}{c}\text { All patients } \\
(n=15)\end{array}$ & $\begin{array}{c}\text { Patients with lung biopsy } \\
(n=8)\end{array}$ \\
\hline Diffuse & $4(27)$ & $3(38)$ \\
Upper lobe predominance & $1(7)$ & $1(13)$ \\
Subpleural predominance & $1(7)$ & $0(0)$ \\
\hline
\end{tabular}

Percentage of total is indicated in parentheses. 
Table 5: Findings on follow-up HRCT scans in patients with SFTPC gene mutation.

\begin{tabular}{llc} 
& & All patients $(\mathbf{n}=\mathbf{1 1})$ \\
\hline $\begin{array}{l}\text { Ground-glass opacities } \\
\mathrm{n}=10\end{array}$ & Stable & $6(55)$ \\
& Increased & $3(27)$ \\
$\mathrm{n}=10$ & Decreased & $1(9)$ \\
Pung cyst & Appeared & $5(45)$ \\
& Increased & $5(45)$ \\
\hline
\end{tabular}

Percentage of total is indicated in parentheses. 
Table 6: Radiological-pathological correlation.

\begin{tabular}{|c|c|c|c|c|c|c|c|c|c|c|c|}
\hline \multirow{3}{*}{ Patient } & \multirow{3}{*}{$\begin{array}{l}\text { Age at } \\
\text { biopsy } \\
\text { (months) }\end{array}$} & \multirow{3}{*}{$\begin{array}{l}\text { Age at initial } \\
\text { HRCT } \\
\text { (months) }\end{array}$} & \multirow{3}{*}{$\begin{array}{c}\text { Cystic dilatation } \\
\text { of the respiratory } \\
\text { bronchioli }\end{array}$} & \multirow{3}{*}{$\begin{array}{c}\text { Cystic dilatation } \\
\text { of the alveolar } \\
\text { duct }\end{array}$} & \multirow{3}{*}{$\begin{array}{l}\text { Muscle hyperplasia of the } \\
\text { respiratory bronchioli }\end{array}$} & \multirow{3}{*}{$\begin{array}{l}\text { Increased number of } \\
\text { macrophages in the } \\
\text { alveolar lumen }\end{array}$} & \multirow{3}{*}{$\begin{array}{l}\text { Alveolar septal } \\
\text { thickening }\end{array}$} & \multicolumn{4}{|c|}{ HRCT findings } \\
\hline & & & & & & & & \multicolumn{2}{|c|}{ Ground-glass opacities } & \multicolumn{2}{|c|}{ Lung cysts } \\
\hline & & & & & & & & Initial & Follow-up & Initial & Follow-up \\
\hline 1 & 4 & 5 & + & + & - & + & + & + & - & + & + \\
\hline 2 & 7 & 8 & + & + & - & + & + & + & - & + & + \\
\hline 3 & 6 & 40 & - & - & - & + & + & - & + & + & + \\
\hline 4 & 4 & 2 & + & + & - & + & + & + & + & - & + \\
\hline 5 & 4 & 6 & + & + & - & + & + & + & + & + & + \\
\hline 6 & 4 & 1 & + & + & + & + & + & + & - & - & + \\
\hline 7 & 6 & 3 & + & + & + & + & + & + & + & - & + \\
\hline 8 & 3 & 2 & + & + & . & + & + & + & - & - & + \\
\hline
\end{tabular}


Figure 1

Mechrietal
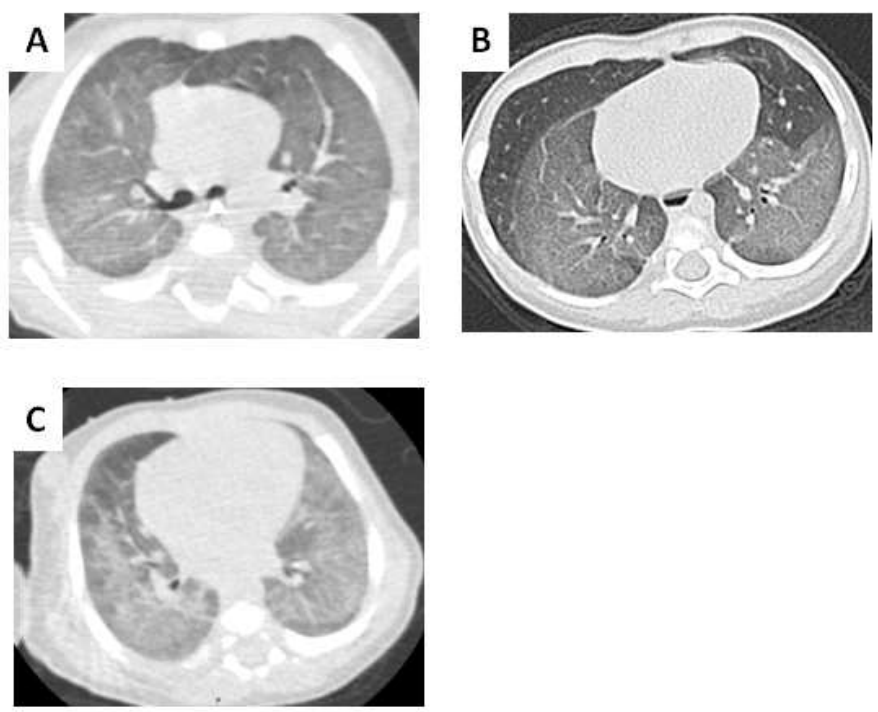

Fig. 1: Four-year-old boy with SFTPC mutation. HRCT section through the carina shows diffuse and uniform ground-glass opacities (A).Two-year-old girl with SFTPC mutation. Initial HRCT (at 3 months) shows homogenous ground-glass opacity in the lower lobes (B). One month old girl with compound heterozygous missense ABCA3 mutations. Initial HRCT shows ground-glass opacity in the lower lobes (C).

$190 \times 254 \mathrm{~mm}(96 \times 96 \mathrm{DPI})$ 
Figure 2

Mechriet al
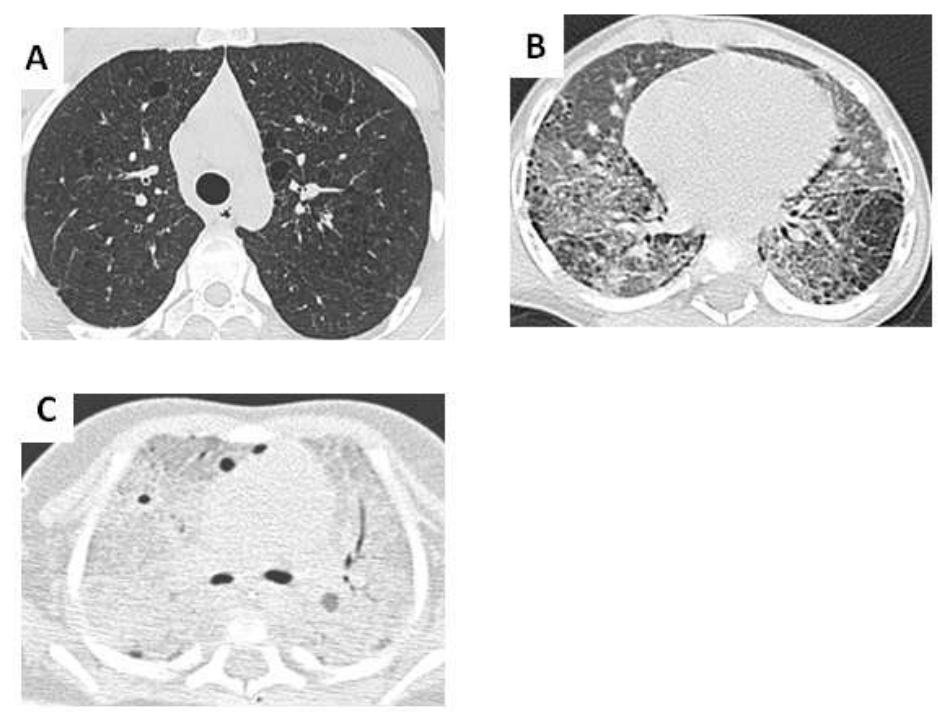

Fig. 2: Two-year-old girl with SFTPC mutation. Initial HRCT (at 16 months) shows paraseptal emphysema (curved arrow) associated with widespread cystic airspaces and diffuse ground-glass opacities (A). Seventeen-year-old boy with SFTPC mutation. The HRCT done at 14 -year -old showed isolated lung cysts with thin wall and variable sizes (B). One month old girl with compound heterozygous missense ABCA3 mutations. Initial HRCT shows association of ground-glass opacity, alveolar condensations and lung cysts (C). $190 \times 254 \mathrm{~mm}(96 \times 96$ DPI $)$ 
Figure 3

Mechriet al

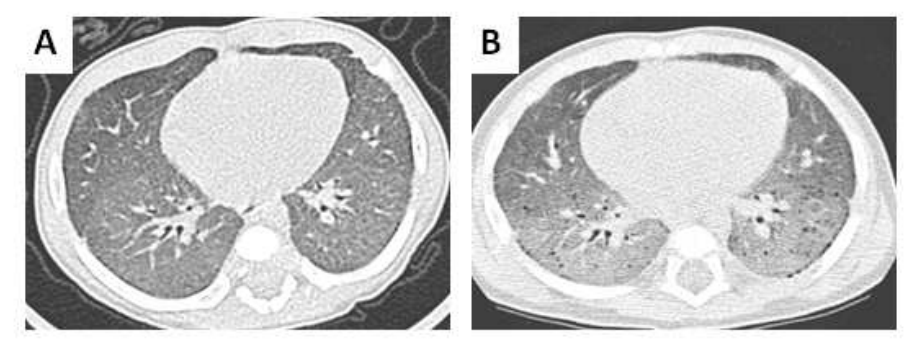

A one-year-old boy with SFTPC gene mutation. The initial computed tomography shows diffuse ground-glass opacities (A). The follow-up HRCT scan done 14 months later revealed the appearance of new lung cysts in lower lobes surimposed on diffuse ground-glass opacities (B). $190 \times 254 \mathrm{~mm}(96 \times 96 \mathrm{DPI})$ 
Figure 4

Mechriet al
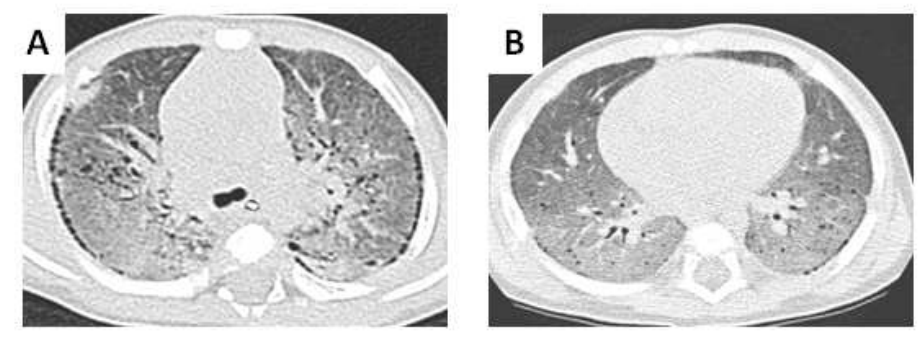

Fig. 4: Two-year-old girl with SFTPC gene mutation. Initial HRCT scan diffuse shows lung cysts with subpleural predominance associated with diffuse ground-glass opacities (A). The follow-up HRCT scan done 6 months later, revealed an increase in the number and size of lung cysts associated with stable ground-glass opacities (B). $190 \times 254 \mathrm{~mm}(96 \times 96 \mathrm{DPI})$ 

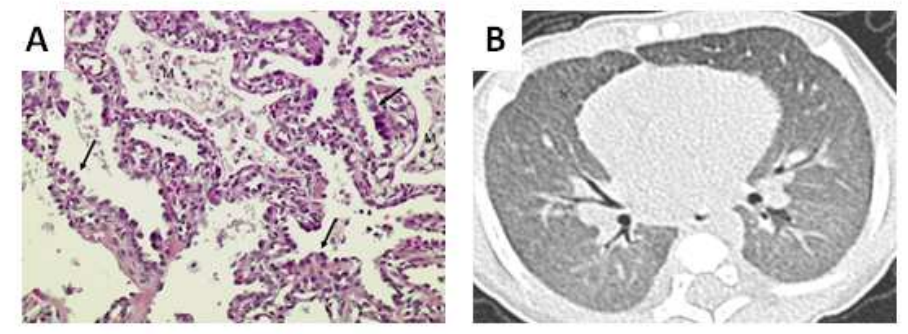

A one-year old boy with SFTPC gene mutation who underwent lung biopsy in the middle lobe. Highpower photomicrograph (original magnification $\times 200$, hematoxylin eosine $[\mathrm{H}-\mathrm{E}]$ stain) $(\mathrm{A})$ shows numerous macrophages in alveoli (M) and type II pneumocytes hyperplasia (straight arrows) with septal thickening. HRCT section through the middle lobe (B) shows diffuse ground glass opacity. $190 \times 254 \mathrm{~mm}(96 \times 96 \mathrm{DPI})$ 
Figure 6

Mechriet al

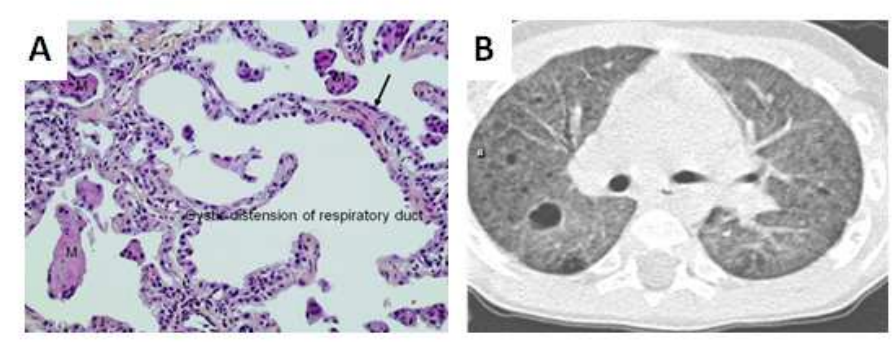

A 3-year old girl with SFTPC gene mutation who underwent lung biopsy in the right upper lobe. High- power photomicrograph (original magnification $\times 200$, hematoxylin eosine $[\mathrm{H}-\mathrm{E}]$ stain) (A) shows cystic distension of respiratory ducts (curved arrow), numerous macrophages in alveoli (M) and type II pneumocytes hyperplasia (straight arrows). HRCT section through the upper lobes (B) shows diffuse lung cysts associated with diffuse ground glass opacities.

$190 \times 254 \mathrm{~mm}(96 \times 96 \mathrm{DPI})$ 


\section{Surfactant Protein C Gene (SFTPC) Mutation-Associated Lung Disease: High-Resolution Computed Tomography (HRCT) Findings and its Relation to Histological Analysis}

M. Mechri ${ }^{* 1,2,3}$, R. Epaud ${ }^{* 2,3,4,5}$, S. Emond ${ }^{1,6,7}$, A. Coulomb ${ }^{2,3,8}$, F. Jaubert ${ }^{1,6,8}$, A. Tarrant ${ }^{1,2,3}$, D. Feldmann $^{2,3,9}$, F. Flamein ${ }^{2,4}$, A. Clement ${ }^{2,3,4,5} \mathrm{~J}_{\text {. de Blic }}^{5,6,7}$, R. Abou Taam ${ }^{5,6,7}$, F. Brunelle ${ }^{1,6,7}$, H. Ducou le Pointe ${ }^{1,2,3}$

${ }^{1}$ Pediatric Radiology Department. ${ }^{2}$ UPMC Univ Paris 06, France; ${ }^{3}$ AP-HP, Hôpital Armand Trousseau, ${ }^{4}$ INSERM UMR_S U938, Paris, France; ${ }^{5}$ Pediatric Pulmonary Department; ${ }^{6}$ Université Paris Descartes ; ${ }^{7}$ AP-HP, Hôpital Necker Enfants Malades, Paris, France; ${ }^{8}$ Histological department, ${ }^{9}$ Biochemistry Department.

*These authors contributed equally to this work and should be considered as first author.

The authors have no conflicts of interest to disclose.

Running title: HRCT and histological finding of SFTPC mutations

Keywords: surfactant protein C, HRCT, Histological.

\section{Corresponding authors:}

\section{Pr. Hubert Ducou Le pointe}

Pediatric Radiology Department

Hôpital d'Enfants Armand Trousseau

26 Avenue du Dr Arnold Netter

F-75571 Paris cedex 12, France

Email : hubert.ducou-le-pointe@trs.aphp.fr 


\begin{abstract}
:
Aim of the study

Determine high-resolution tomography (HRCT) scan characteristics in children with SFTPC mutation and correlate them to histological findings.

Patients and Methods

This retrospective multicenter study included 15 children (7 females and 8 males) with SFTPC mutations. HRCT scans have been performed in all the children and lung biopsies in 8 children.

Results

From all signs assessed on initial HRCT scans, ground-glass opacities $(\mathrm{n}=14,93 \%)$ and lung cysts $(n=6,40 \%)$ were predominant. Interlobular septal thickening $(n=1,7 \%)$, air space consolidation $(n=1,7 \%)$, paraseptal emphysema $(n=2,13 \%)$, and pulmonary nodules $(n=1,7$ $\%)$ were also found. Histological analysis revealed accumulation of macrophages in the alveolar lumen, type II pneumocyte hyperplasia, and alveolar septal thickening. Dilatation of the respiratory bronchiole and alveolar duct associated with muscular hyperplasia were also described. Interestingly, lung cysts on HRCT scans were associated with dilatation of terminal bronchioli and alveolar duct in lung biopsies.

\section{Conclusion}

In children with SFTPC mutations, HRCT scan finding were highly correlated to the histological findings and, as such, represent a useful tool to identify patients that may require SFTPC gene sequencing.
\end{abstract}




\section{Introduction:}

Idiopathic forms of interstitial lung disease (ILD) in children are associated with a wide spectrum of underlying pathologies. Until recently, a single classification system has been used, regardless of age, and children with ILD were forced into published adult disease classification systems ${ }^{1}$. In 2007, a multi-disciplinary working group of pediatric pathologists, clinicians and radiologist (the Children's Interstitial Lung Disease (chILD) Research Cooperative) designed and conducted a retrospective clinical, radiographic and histopathologic review and proposed a new classification system for children with diffuse lung disease (chILD syndrome) ${ }^{2}$. In this classification, surfactant genetic abnormalities account for more than $10 \%$ of the patients reviewed. Pulmonary surfactant is a mixture of phospholipids and specific proteins secreted by type II epithelial cell to reduce the alveolar surface tension at the air-liquid interface and prevent end-expiratory atelectasis ${ }^{3}$. The hydrophobic surfactant protein SP-C, play an important role in the spreading and stabilization of phospholipids films in the alveolus ${ }^{3}$ highlighted by lung disease caused by inherited abnormalities in its genes ${ }^{4,5}$. Since the first description by Nogee et al., more than 35 dominantly expressed mutations in the SFTPC gene have been identified in association with acute or chronic lung disease in patients ranging in age from newborn to adults ${ }^{6-10}$. These mutations, whether inherited or spontaneous are always found in an autosomal dominant form, the most frequently observed (nearly $50 \%$ ) being p.[Ile73Thr] or I73T). The phenotype associated with SFTPC mutations is eminently variable. Indeed, neonatal forms leading to death in the first years of life as well as childhood and adult forms with chronic respiratory disease have been observed. The effects of SFTPC mutations on surfactant homeostasis have not been clearly elucidated. In an in vitro study off cells with a SFTPC deletion, accumulation of misfolded proSP-C in the Endoplasmic reticulum (ER) causes disruption of the ubiquitin/proteasome system ${ }^{11}$, activates apoptosis and interferes with non mutated protein 
synthesis. It results in the release of pro-inflammatory cytokines and enhances T-cell and fibroblast recruitment ${ }^{12}$.

Although consensus exists on the need to consider early open lung in children with ILD, genetic testing for SFTPC mutation has become widespread and may be performed relatively quickly. In addition, recent advances in imaging techniques have contributed to more efficiently predict histological findings. Indeed, HRCT has been proposed for either diagnosis or following ILD precluding the need to obtain a surgical biopsy ${ }^{13,14}$. Thus, the aim of the present study was to determine HRCT features of children with SFTPC mutation and to bring new insight in the correlation between HRCT and histological findings. To address these questions HRCT finding of a cohort of 15 children with interstitial chronic lung disease related to SFTPC gene mutations were retrospectively reviewed and subsequently correlated with histological analysis when lung biopsies were available. 


\section{Patients and Methods}

This study is a retrospective study performed in 2 university hospital-based pediatric pulmonology practice (Hôpital Armand Trousseau and Hôpital Necker enfants-malades, Paris, France) for a 15-year period (1993-2008). The protocol was accepted by the Committee for the protection of individuals in Biochemical research as required by French legislation and written informed consent was obtained from the patients or their next of kin included in this study.

\section{Patients}

The characteristics of patients are summarized in Table 1. Fifteen children, 7 females and 8 males with a definitive diagnosis of SFTPC gene mutation were included. All the patients were immunocompetent and screening for metabolic, infectious, and immunological etiologies was negative. Genetic and clinical characteristics of all these patients have been described in detail in previous reports ${ }^{8,15}$. Three patients, members, or relatives of a same family, have also been reported previously ${ }^{6}$. Median age of onset was 2 (range 0-18) months. Three patients had neonatal respiratory distress, and symptom onset was associated with acute bronchiolitis in 7 (47\%) patients. Cough, tachypnea, and gastroesophageal reflux and failure to thrive were initially noticed in all the children. Physical examination at presentation revealed tachypnea and retraction in all patients. Low oxygen saturation $(<95 \%)$ was observed initially in all patients. Treatment are summarized in table 1 and included methylprednisolone pulse $(n=15)$, hydroxychloroquin $(n=8)$ and azithromycin $(n=5)$. Median follow-up was 3.1 (1-17.3) years. At the end of the study, all the children were alive but 11 patients (73\%) were still symptomatic with cough, dyspnea or exercise intolerance. 


\section{HRCT scan and image analysis}

CT examinations were performed with two helical scanners and two multidetector CT scanners. In Armand Trousseau hospital, Elscint (CT Twin) with scan acquisition at $120 \mathrm{kV}$, 120 mAs and after 2003 a Philips (Mx 8000 IDT32) 16 slice multidetector CT was used with scan acquisition at the $90 \mathrm{kV}, 90 \mathrm{mAs}$. In Necker Hospital, General Electric helical CT (Prospeed) with scan acquisition at $140 \mathrm{kV}, 130 \mathrm{mAs}$, and after 2005 a General Electric (LightSpeed) 64 slice multidetector CT was used with scan acquisition at the $100 \mathrm{kV}, 100 \mathrm{~mA}$. All the patients underwent non-contrast-enhanced incremental (at intervals of 3 to $10 \mathrm{~mm}$ ) or helical HRCT scan with a collimation of 16 X $1 \mathrm{~mm}$. Scans were obtained from the level of apices to the diaphragm. Image reconstruction was performed with a high special frequency algorithm. All CT scans were performed before the diagnosis, and none of the patients were receiving treatment at the time of first HRCT. The HRCT scans (initial and follow-up) were reviewed and interpreted by 2 experienced pediatric radiologists who arrived at their interpretations by consensus without knowledge of histological parameters. HRCT scan analysis was performed with reference to a conventional model in line with Austin's definition

The scans were assessed for the presence, extent, and distribution of elementary lesions, such us areas of ground-glass opacity, lung cysts, lung consolidation, interlobular and intralobular septal thickening, thickening of bronchovascular bundles, and nodules (centrolobular or other). The anatomical distribution was classified as central (a predominance of abnormalities in the inner two-thirds of the lung), peripheral (a predominance of abnormalities in the outer one-third of the lung or along the interlobar fissures), or random (no central or peripheral predominance). The zonal predominance of abnormalities was assessed as being upper, intermediate lower, or random. Upper lung zone predominance was considered present when the extent of abnormalities was greatest above the level of the 
tracheal carina; intermediate was considered between the carina and inferior pulmonary veins, and lower zone predominance was considered present when disease extent was greatest below this level. Specific involvement or sparing of the subpleural region $(<1 \mathrm{~cm}$ from the pleura) was assessed. Ground-glass opacities describe lung that is higher in attenuation than a normal lung on inspiration but lower than the attenuation of bronchial walls and blood vessels so that these lung markings remain visible ${ }^{16}$. The term lung cyst is used to refer to a well-defined, rounded, and circumscribed lesion, with a wall that may be uniform or varied in thickness but which is usually thin (with thickness of less than $3 \mathrm{~mm}$ ) ${ }^{17}$. Because this study was retrospective, the intervals of follow-up HRCT scanners were highly centre-dependent and based on the decision of the physician in charge of the child. Only HRCT scanners available ware taking into consideration for analysis. Control HRCT scans were obtained from 6 agematched patients with a definitive diagnosis of $A B C A 3$ (ATP-binding cassette subfamily A, member 3) mutations, a gene expressed in lamellar bodies of alveolar type II cells which has a critical role in surfactant storage and homeostasis ${ }^{18}$. Among them, 2 patients carried homozygous missense mutations, 3 patients carried compound heterozygous missense mutations and 1 child had compound heterozygous missense and nonsense mutations. Median age at HRCT scans was 2 months (range 1 month to 12 years).

\section{Lung biopsies and their analysis}

Surgical lung biopsies ranging from 0.5 to $1 \mathrm{~cm}$ were obtained from different lobes in 8 children at the age of 3 to 7 months (mean age, 4 months) before treatment onset. Biopsy sites are summarized in Table 1. Specimens were further fixed in formalin and embedded in paraffin. A five-micrometer tissue section was stained with $\mathrm{H}$ and $\mathrm{E}$ stain (hematoxylin and eosin stain). Slides were examined by 2 pathologists. Radiology-pathology correlation was performed in 8 cases. All 8 children had only 1 open lung biopsy. 


\section{Results:}

\section{Initial HRCT findings}

The median age at initial HRCT scanner was 4 (range 1-40) months (one child had the scanner performed 40 months after the diagnosis for technical reasons). High-resolution CT findings are summarized in Table 2. The most frequent abnormalities identified on initial HRCT were ground-glass opacities (93\%) and lung cysts (40\%). Other abnormalities noted included interlobular septal thickening (7\%), air space consolidation (7\%), paraseptal emphysema (13\%), and pulmonary nodules (7\%). In comparison, ground-glass opacities were constantly observed in all of the 6 patients with ABCA3 mutations. However, opacities were more prominent with presence in some cases of alveolar condensations.

Bilateral ground-glass opacities were shown in 14 children (Table 3), either as an isolated finding $(60 \%)$ or as part of a mixed pattern with lung cysts (33\%), air space consolidation (7 $\%)$, paraseptal emphysema, and centrolobular nodules (7 \%). They were homogeneously diffuse in 9 cases $(60 \%)$ (Figure 1A). When a patchy distribution was present, this was noted to have basal subpleural predominance in 1 case $(7 \%)$, predominance for the lower lobes in 2 cases $(13 \%)$ (Figure 1B), a central predominance in 1 case $(7 \%)$, and a predominance for the posterior portions of the lung in 1 case $(7 \%)$.

Thin-walled $(<1 \mathrm{~mm})$ lung cysts of varying sizes were seen in 6 infants (40\%) (Table 4), either as an isolated finding (7\%) (Figure $2 \mathrm{~A})$, or as a mixed pattern with areas of groundglass opacities (33\%), paraseptal emphysema (13\%) (Figure 2B), septal thickening (7\%), and non-septal thickening ( $7 \%$ ). A predominantly subpleural distribution was seen in 1 child (7\%); diffuse cysts with random distribution was seen in 4 cases $(27 \%)$ and upper lung zone predominance was seen in 1 case $(7 \%)$.

\section{Follow-up HRCT scan}


Follow-up CT scans were performed on 11 of the 15 children. The median follow-up interval was 8 (range 3-12) months. Eight patients had 1 follow-up HRCT scan, 2 patients had 2 follow-up HRCT scans ( 3 and 9 months and 4 and 9 months, respectively), and 1 patient had 3 follow-up HRCT scans (3, 6 and 12 months). Evaluation of the follow-up HRCT scans (Table 5) revealed the development of lung cysts in 5 patients (45\%) who had previously only had ground-glass opacities (Figures 3A and 3B). These new cystic changes were associated with a stable pattern of ground-glass opacities in 2 cases, decrease in the degree of ground-glass opacities in 1 case, and an aggravation of this pattern in 2 cases. These cysts were diffuse in all cases but showed a predilection for different regions of the lung: upper lobes $(n=1)$, basal subpleural $(n=1)$, peripheral $(n=1)$, and central $(n=1)$. In 1 case, lung cysts were homogenous and diffuse. Patients who had previously documented cysts on their initial HRCT scans also demonstrated change when follow-up HRCT was performed. In 5 patients (45\%), we noted an increase in the number or size of preexisting lung cysts (Figures 4A and 4B), which were associated with stable ground-glass opacities $(n=4)$, aggravated ground-glass opacities $(n=1)$, and progressive pulmonary fibrosis $(n=1)$. The HRCT findings of pulmonary fibrosis consisted of bilateral and diffuse honeycombing, septal and non-septal thickening, and thickening of bronchovascular bundles and distortion of pulmonary fissures. In 1 patient, we observed persistent isolated ground-glass opacities.

\section{Pathology findings}

Eight of the 15 patients (53\%) underwent lung biopsy the median age at biopsy being 4 (range 3-7) months. Histological analysis revealed 2 main types of lesions. The first type occurred in the alveolar lumen, were we observed the following changes: accumulation of macrophages intermingled with few inflammatory cells and cholesterol cleft, type II pneumocyte hyperplasia, and alveolar septal thickening by primitive mesenchymal cells and lymphocytes either isolated or clustered (Figure 5A). These lesions were diffuse in 7 cases (90 
$\%)$ and patchy in 1 case $(13 \%)$. The second type of lesion corresponds to dilatation of the respiratory bronchiole and alveolar duct in 7 cases $(88 \%)$ associated with muscular hyperplasia in 2 patients (25\%) (Figure 6A). There was no interstitial pulmonary fibrosis or alveolar proteinosis observed.

\section{Relation between HRCT and pathology findings}

Radiological-pathological confrontation is summarized in Table 6. Ground-glass opacities on HRCT were observed in all the patients except 1 in which the CT scan was performed late (40 months). All these children also have diffuse alveolar septal thickening by primitive mesenchymal cells and lymphocytes, intra-alveolar accumulation of macrophages, and type II pneumocyte hyperplasia. Small lung cysts were observed initially in half of the children but appeared during follow-up in all the cases. They were related with dilatation of the terminal bronchioles and alveolar duct which were noticed in all but one biopsy.

\section{Discussion:}

In the present study, we have shown for the first time in a large cohort of children with SFTPC mutation associated lung diseases that HRCT pattern were characterized with 2 main abnormalities: ground-glass opacities that were predominately diffuse but can be patchy in some cases and lung cysts with thin wall and different sizes.

Ground-glass opacities have been commonly described in previous reports ${ }^{6,19,20}$. They are predominately diffuse but can be patchy in some cases. In our series, they were present in all the patients except one in whom the HRCT scan was done late. We also note in our study the high frequency of cystic lesions on HRCT scan. They appeared in $45 \%$ of the children during follow-up and increased in number in $45 \%$. Similar change during follow-up is typical of surfactant abnormality and was noted by Brody ${ }^{16}$. In our series, ground-glass attenuation 
decreased in intensity with age, whereas small lung cysts usually became more prominent over time.

This HRCT presentation, namely the ground-glass opacities and cystic patterns is, nonetheless, not specific of SFTPC associated disorders. We have shown that this presentation may also be observed in children with $A B C A 3$ mutations as previously described ${ }^{21}$.However, the high frequency of SFTPC associated disorders in children ILD ${ }^{2,7}$, the feasibility of SFTPC genetic analysis as well as the difficulty to perform lung biopsy in patients with fragile respiratory condition strongly encourage to perform SFTPC genetic screening before lung biopsy in children with ground-glass opacities associated with cystic lung changes on HRCT scanner.

In the literature, there are histological studies of patients with SFTPC gene mutations showing 4 histological patterns: desquamative interstitial pneumonitis (DIP), nonspecific interstitial pneumonitis(NSIP), (UIP) and pulmonary alveolar proteinosis ${ }^{7,16,22}$ in children and usual interstitial pneumonitis (UIP) in adults. In children, DIP and NSIP have also been described in patients with mutations in the ATP-binding cassette transporter A3 (ABCA3) gene ${ }^{21}$. Chibbar et al. showed that both children and adults with NSIP and UIP patterns, respectively, carried a common mutation within the SFTPC gene ${ }^{23}$. Thomas et al. described a mutation in SFTPC gene associated with large kindred with familial form of pulmonary fibrosis, including adults with the most common pathological subset of pulmonary fibrosis, UIP, and children with cellular NSIP ${ }^{24}$. Brasch reported histological patterns of NSIP and pulmonary alveolar proteinosis in a 13-month-old infant with a de novo heterozygous missense mutation of the SFTPC gene ${ }^{20}$. The histological findings were classified as DIP because of an increased number of macrophages in the alveolar lumen ${ }^{25}$ and as NSIP and UIP because of the numerous inflammatory cells in the alveolar septum ${ }^{26,27}$. In this study, we have related ground-glass opacities on HRCT to diffuse alveolar septal thickening by primitive 
mesenchymal cells and lymphocytes, intra-alveolar accumulation of macrophages, and type II pneumocytes hyperplasia. Small lung cysts were related to dilatation of the respiratory bronchioli and alveolar duct. On initial HRCT scan analysis, large cystic lung changes in the periseptal and subpleural regions were that of subpleural emphysema. On lung biopsies, millimetric small cysts corresponding to a dilatation of respiratory bronchioli and alveolar ducts, sometimes in subpleural area and periseptal regions, were observed, whereas histological emphysema was not present. Large cyst $(>1 \mathrm{~mm})$ probably corresponds to emphysema, whereas small cyst may be in part due to cystic dilatation of the proximal part of the acini.

After natural exposure, CT scan is the greatest contributor to total radiation exposure and Brenner et al. notes that the evidence is "convincing" that the radiation dose from CT scans can lead to cancer induction in adults and "very convincing" in the case of children ${ }^{28}$. Hence, it is of importance to adjust protocols in order to reduce unnecessary radiation exposure from CT. Exposure parameters have considerably decreased during the study, but these efforts must be sustained. In this context, we also recommend to use a sequential technique during followup, including for multi detector CT.

With this report as our basis, the presence of bilateral ground-glass opacity or a combination of ground-glass opacities and cysts suggests the diagnosis of SFTPC mutation associated disorders and strongly encourage to perform genetic screening. We believe that this study is of value in highlighting this rare condition, and future prospective studies in children and adults are needed to further characterize CT findings in surfactant dysfunction disorders.

\section{Acknowledgement}

We thank all the members of the affected families and their referring clinicians for their collaborative participation in this study. This work was supported by Assistance PubliqueHôpitaux de Paris. "Surfactant Disorders and Chronic Lung Disease (APSE)," Clinical Trials gov. number, NCT00493363. 


\section{References:}

1. Demedts M, Costabel U. ATS/ERS international multidisciplinary consensus classification of the idiopathic interstitial pneumonias. Eur Respir J 2002;19(5):794796.

2. Deutsch GH, Young LR, Deterding RR, Fan LL, Dell SD, Bean JA, Brody AS, Nogee LM, Trapnell BC, Langston C, Albright EA, Askin FB, Baker P, Chou PM, Cool CM, Coventry SC, Cutz E, Davis MM, Dishop MK, Galambos C, Patterson K, Travis WD, Wert SE, White FV. Diffuse lung disease in young children: application of a novel classification scheme. Am J Respir Crit Care Med 2007;176(11):1120-1128.

3. Weaver TE, Conkright JJ. Function of surfactant proteins B and C. Annu Rev Physiol 2001;63:555-578.

4. Cole FS, Hamvas A, Nogee LM. Genetic disorders of neonatal respiratory function. Pediatr Res 2001;50(2):157-162.

5. Hamvas A. Inherited surfactant protein-B deficiency and surfactant protein-C associated disease: clinical features and evaluation. Semin Perinatol 2006;30(6):316326.

6. Abou Taam R, Jaubert F, Emond S, Le Bourgeois M, Epaud R, Karila C, Feldmann D, Scheinmann P, de Blic J. Familial interstitial disease with I73T mutation: A mid- and long-term study. Pediatr Pulmonol 2009;44(2):167-175.

7. Cameron HS, Somaschini M, Carrera P, Hamvas A, Whitsett JA, Wert SE, Deutsch G, Nogee LM. A common mutation in the surfactant protein $\mathrm{C}$ gene associated with lung disease. J Pediatr 2005;146(3):370-375.

8. Guillot L, Epaud R, Thouvenin G, Jonard L, Mohsni A, Couderc R, Counil F, de Blic J, Taam RA, Le Bourgeois M, Reix P, Flamein F, Clement A, Feldmann D. New surfactant protein $\mathrm{C}$ gene mutations associated with diffuse lung disease. J Med Genet 2009;46(7):490-494.

9. Hamvas A, Nogee LM, White FV, Schuler P, Hackett BP, Huddleston CB, Mendeloff EN, Hsu FF, Wert SE, Gonzales LW, Beers MF, Ballard PL. Progressive lung disease and surfactant dysfunction with a deletion in surfactant protein $\mathrm{C}$ gene. Am $\mathrm{J}$ Respir Cell Mol Biol 2004;30(6):771-776.

10. Lawson WE, Grant SW, Ambrosini V, Womble KE, Dawson EP, Lane KB, Markin C, Renzoni E, Lympany P, Thomas AQ, Roldan J, Scott TA, Blackwell TS, Phillips JA, 3rd, Loyd JE, du Bois RM. Genetic mutations in surfactant protein C are a rare cause of sporadic cases of IPF. Thorax 2004;59(11):977-980.

11. Mulugeta S, Nguyen V, Russo SJ, Muniswamy M, Beers MF. A surfactant protein C precursor protein BRICHOS domain mutation causes endoplasmic reticulum stress, proteasome dysfunction, and caspase 3 activation. Am J Respir Cell Mol Biol 2005;32(6):521-530.

12. Mulugeta $S$, Beers MF. Surfactant protein C: its unique properties and emerging immunomodulatory role in the lung. Microbes Infect 2006;8(8):2317-2323.

13. Hunninghake GW, Zimmerman MB, Schwartz DA, King TE, Jr., Lynch J, Hegele R, Waldron J, Colby T, Muller N, Lynch D, Galvin J, Gross B, Hogg J, Toews G, Helmers R, Cooper JA, Jr., Baughman R, Strange C, Millard M. Utility of a lung biopsy for the diagnosis of idiopathic pulmonary fibrosis. Am J Respir Crit Care Med 2001;164(2):193-196.

14. Silva CI, Muller NL, Hansell DM, Lee KS, Nicholson AG, Wells AU. Nonspecific interstitial pneumonia and idiopathic pulmonary fibrosis: changes in pattern and distribution of disease over time. Radiology 2008;247(1):251-259. 
15. Thouvenin G, Taam RA, Flamein F, Guillot L, Le Bourgeois M, Reix P, Fayon M, Counil F, Depontbriand U, Feldmann D, Pointe HD, de Blic J, Clement A, Epaud R. Characteristics of disorders associated with genetic mutations of surfactant protein $\mathrm{C}$. Arch Dis Child 2010.

16. Brody AS. Imaging considerations: interstitial lung disease in children. Radiol Clin North Am 2005;43(2):391-403.

17. Koyama M, Johkoh T, Honda O, Tsubamoto M, Kozuka T, Tomiyama N, Hamada S, Nakamura H, Akira M, Ichikado K, Fujimoto K, Rikimaru T, Tateishi U, Muller NL. Chronic cystic lung disease: diagnostic accuracy of high-resolution CT in 92 patients. AJR Am J Roentgenol 2003;180(3):827-835.

18. Shulenin S, Nogee LM, Annilo T, Wert SE, Whitsett JA, Dean M. ABCA3 gene mutations in newborns with fatal surfactant deficiency. $N$ Engl $J$ Med 2004;350(13):1296-1303.

19. Nogee LM, Dunbar AE, 3rd, Wert S, Askin F, Hamvas A, Whitsett JA. Mutations in the surfactant protein $\mathrm{C}$ gene associated with interstitial lung disease. Chest 2002;121(3 Suppl):20S-21S.

20. Brasch F, Griese M, Tredano M, Johnen G, Ochs M, Rieger C, Mulugeta S, Muller $\mathrm{KM}$, Bahuau M, Beers MF. Interstitial lung disease in a baby with a de novo mutation in the SFTPC gene. Eur Respir J 2004;24(1):30-39.

21. Doan ML, Guillerman RP, Dishop MK, Nogee LM, Langston C, Mallory GB, Sockrider MM, Fan LL. Clinical, radiological and pathological features of ABCA3 mutations in children. Thorax 2008;63(4):366-373.

22. Tredano M, Griese M, Brasch F, Schumacher S, de Blic J, Marque S, Houdayer C, Elion J, Couderc R, Bahuau M. Mutation of SFTPC in infantile pulmonary alveolar proteinosis with or without fibrosing lung disease. Am J Med Genet A 2004;126(1):18-26.

23. Chibbar R, Shih F, Baga M, Torlakovic E, Ramlall K, Skomro R, Cockcroft DW, Lemire EG. Nonspecific interstitial pneumonia and usual interstitial pneumonia with mutation in surfactant protein $\mathrm{C}$ in familial pulmonary fibrosis. Mod Pathol 2004;17(8):973-980.

24. Thomas AQ, Lane K, Phillips J, 3rd, Prince M, Markin C, Speer M, Schwartz DA, Gaddipati R, Marney A, Johnson J, Roberts R, Haines J, Stahlman M, Loyd JE. Heterozygosity for a surfactant protein $\mathrm{C}$ gene mutation associated with usual interstitial pneumonitis and cellular nonspecific interstitial pneumonitis in one kindred. Am J Respir Crit Care Med 2002;165(9):1322-1328.

25. Lynch DA, Hay T, Newell JD, Jr., Divgi VD, Fan LL. Pediatric diffuse lung disease: diagnosis and classification using high-resolution CT. AJR Am J Roentgenol 1999;173(3):713-718.

26. Katzenstein AL, Myers JL. Nonspecific interstitial pneumonia and the other idiopathic interstitial pneumonias: classification and diagnostic criteria. Am J Surg Pathol 2000;24(1):1-3.

27. Kim TS, Lee KS, Chung MP, Han J, Park JS, Hwang JH, Kwon OJ, Rhee CH. Nonspecific interstitial pneumonia with fibrosis: high-resolution CT and pathologic findings. AJR Am J Roentgenol 1998;171(6):1645-1650.

28. Brenner DJ, Hall EJ. Computed tomography--an increasing source of radiation exposure. N Engl J Med 2007;357(22):2277-2284. 
Fig. 3: A one-year-old boy with SFTPC mutation. The initial computed tomography shows diffuse ground-glass opacities (A). The follow-up HRCT scan done 14 months later revealed the appearance of new lung cysts in lower lobes surimposed on diffuse ground-glass opacities (B).

Fig. 4: Two-year-old girl with SFTPC mutation. Initial HRCT scan diffuse shows lung cysts with subpleural predominance associated with diffuse ground-glass opacities (A). The followup HRCT scan done 6 months later, revealed an increase in the number and size of lung cysts associated with stable ground-glass opacities (B).

Fig. 5: A one-year old boy with SFTPC mutation who underwent lung biopsy in the middle lobe. High-power photomicrograph (original magnification $\times 200$, hematoxylin eosine $[\mathrm{H}-\mathrm{E}]$ stain) (A) shows numerous macrophages in alveoli (M) and type II pneumocytes hyperplasia (straight arrows) with septal thickening. HRCT section through the middle lobe (B) shows diffuse ground glass opacity.

Fig. 6: A 3-year old girl with SFTPC mutation who underwent lung biopsy in the right upper lobe. High- power photomicrograph (original magnification $\times 200$, hematoxylin eosine $[\mathrm{H}-\mathrm{E}]$ stain) (A) shows cystic distension of respiratory ducts (curved arrow), numerous macrophages in alveoli (M) and type II pneumocytes hyperplasia (straight arrows). HRCT section through the upper lobes (B) shows diffuse lung cysts associated with diffuse ground glass opacities. 